

AJCS 15(06):827-834 (2021)

ISSN:1835-2707

doi: 10.21475/ajcs.21.15.06.p2903

\title{
Application of saline tolerant bacteria and soil ameliorants improved growth, yield and nutrient uptake of tomato in saline land
}

\author{
Nurul Aini ${ }^{1 *}$, Wiwin Sumiya Dwi Yamika ${ }^{1}$, Luqman Qurata Aini ${ }^{2}$ and Agus Prayitno Kurniawan ${ }^{1}$ \\ ${ }^{1}$ University of Brawijaya, Faculty of Agriculture, Department of Agronomy, \\ Malang 65145, Indonesia \\ ${ }^{2}$ University of Brawijaya, Faculty of Agriculture, Department of Plant Pests and Diseases, Malang 65145, Indonesia
}

${ }^{*}$ Corresponding author: nra-fp@ub.ac.id

\section{Abstract}

Salinity is one of the problems in agricultural sector widespread in almost all countries in the world, which could reduce crops yield. This research was carried out to study the effect of frequency application of consortium saline-tolerant bacteria isolates with different soil ameliorants on growth and yield of tomato grown saline lands. Research was conducted using split plot design with three replications. Soil ameliorants (Cow manure and gypsum) were the main plot while sub-plots were frequency applications of consortium bacterial isolates (without bacterial, once, twice, three and four times). In this study, bacteria consortium was SN13 (Streptomyces sp.) + SN22 (Bacillus sp.) and SN23 (Corynebacterium sp.) which isolated from the soil of saline-prone regions of Lamongan, in coastal East Java Indonesia. Results showed that gypsum and cow manure as soil ameliorant did not give significant effect on yield and nutrient uptake of tomato while application of saline-tolerant bacteria was able to improve yield and nutrient uptake of tomato. However, the four times application of saline-tolerant bacteria significantly improved plant height (23.36\%), leaves area (96,49\%), total chlorophyll content (11.86\%), dry weight of plant (103.59\%), fresh weight of fruit (85.51 \%), $\mathrm{N}$ uptake (135.22 \%), P uptake (132.99 \%), K uptake (141.68\%) and declined Na uptake (16.28\%), compared to without bacteria application. In conclusion, four times application of saline-tolerant bacteria can alleviate salinity stress of tomato plants in saline lands

Keywords: Bacillus sp., Chlorophyll content, Na uptake, Streptomyces sp.

Abbreviations: ACC_ 1-aminocyclopropane-1-carboxylic acid; APX_ ascorbate peroxidase; ATP_ adenosine tri-phosphate; CAT_ catalase; CEC_cation exchange capacity; CFU_colony forming unit; EC_Electrical Conductivity; IAA_indole-3-acetic acid ; HSD_ honestly significant different; MDA_ malondialdehyde; PGPR_ plant growth promoting rhizobacteria; SAR_ sodium adsorption ratio; SOD_superoxide dismutase; TDI_total dissolved ion; TDS_total dissolved solids

\section{Introduction}

Saline soils, the soils with high concentration of soluble salt, have the ability to decrease the growth and yield of crops. Salinity can be determined by measuring electrical conductivity (EC) of soil water extract, soluble ion concentrations of soil water, mass of total dissolved solids (TDS), or total dissolved ion (TDI) (Hardie and Doyle, 2012). Soil salinity can be classified based on the value of electrical conductivity $(\mathrm{EC})$. Soil can be regarded as saline when it has electrical conductivity more than $4 \mathrm{dS} \mathrm{m}^{-1}$ (equivalent to 40 $\mathrm{mM} \mathrm{NaCl)} \mathrm{(Shrivastava} \mathrm{and} \mathrm{Kumar,} \mathrm{2014).} \mathrm{Water} \mathrm{soluble}$ salts such as Sodium $\left(\mathrm{Na}^{+}\right)$, Magnesium $\left(\mathrm{Mg}^{2+}\right)$, Calcium $\left(\mathrm{Ca}^{2+}\right)$, Potassium $\left(\mathrm{K}^{+}\right)$, Chloride $\left(\mathrm{Cl}^{-}\right)$, Sulfate $\left(\mathrm{SO}_{4}{ }^{2-}\right)$, Carbonate $\left(\mathrm{CO}_{3}^{2-}\right)$ and Bicarbonate $\left(\mathrm{HCO}^{3-}\right)$ accumulated in the soil can potentially cause soil salinity are which rises in the dry season (Sabareshwari and Ramya, 2018; Paul and Lade, 2014). Accumulation of sodium $\left(\mathrm{Na}^{+}\right)$in the soil causes deterioration of physical properties, such as changes in exchangeable soil solutions ion and soil $\mathrm{pH}$, destabilization of soil structure and increased susceptibility to crusting, run off and erosion. It also causes nutritional imbalances in plant (Qadir and Schubert, 2002). Salinity stress affects morphological, physiological and biochemical conditions of a plant (Asghari and Ahmadvand, 2018). Salinity has been reported to decrease photosynthetic rate, total chlorophyll content and cell membrane stability in wheat (Bagdi et al., 2011; Yadav et al., 2011). The main effect of salinity stress is water deficit caused by lowered osmotic potential of soil water, limiting the capacity of plant in absorbing water (Maksimovic and Ilin, 2012; Unlukara et al., 2017). Nutrient availability is one of factors affecting plant growth and development. Salinity stress causes nutrient imbalance of a plant. Salinity increases $\mathrm{Na}$ accumulation in plant tissue and reduces nutrient essential such as nitrogen and potassium content (Sathee et al., 2013; Talei et al., 2012; Gomes et al., 2011). With the right management, saline soil can be used for agricultural purposes. However, the productivity of saline soil is still low. Therefore, proper technological innovations are needed to increase the productivity of saline soils.

Approaches which can be employed to alleviate the effect of salinity stress are plant selection, application of soil ameliorant, and the use of biotechnology such as salinetolerant bacteria. Plants have different tolerance level to salinity stress. Plants can be classified into sensitive, moderately sensitive, moderate tolerant and tolerant, 
according to their ability to grow in different levels of salinity (Grieve et al., 2014). Saline soils can be reclaimed by adding material (organic or inorganic) called ameliorant which can improve the physical or chemical characteristic of the soil. Ahmed et al. (2015) reported that soil physical-chemical characteristics, such as bulk density, organic matter, hydraulic conductivity, $\mathrm{pH}, \mathrm{EC}, \mathrm{SAR}$ and fodder beet yield were significantly improved by the application of soil ameliorants presented as gypsum and farm manure under saline-sodic conditions. Ameliorant decreases salinity level by replacing $\mathrm{Na}^{+}$with another ion such as $\mathrm{Ca}^{2+}$. The common ameliorants used in saline soil are gypsum and cow manure. Gypsum has been reported to be able to decrease level of $\mathrm{Na}^{+}, \mathrm{EC}, \mathrm{pH}$ and Sodium Adsorption ratio (SAR) (AbdelFattah, 2012; Cha-um et al., 2011; Daur and Tatar, 2011). Cow manure is usually applied to increase C-organic of soil. Increasing organic material would decrease the amount of $\mathrm{Na}$ in the soil through $\mathrm{Na}$ absorption by colloids of organic material. Organic manure is used as a long-term ameliorant for degrading the negative effect of saline soil (Buttar et al., 2017).

The use of biotechnology, such as the application of microorganism, plays an important role as bio stimulant and bio fertilizer. It is an alternative to improve plants tolerance to salinity stress. Some bacteria can increase plant growth under salinity stress through mechanisms of producing phytohormones such as auxin, IAA and ACC deaminase (Egamberdieva et al., 2009; Iqbal et al., 2016; Pourbabaee et al., 2016; Yu et al., 2016). Rhizobacteria has also been reported to increase salt-tolerance in plant through regulation of plant antioxidant enzymes such as SOD, CAT, $A P X$, and MDA, which reduce oxidative stress in plant (Yilmaz and Kulaz, 2019). Utilization of indigenous bacteria from areas containing high salinity will be more effective than introducing bacteria from other environments due to their tolerance to saline condition. Some bacteria isolated from rhizosphere of plants grown in saline land can be called saline-tolerant bacteria. Combining the effect of applying saline-tolerance bacteria and soil ameliorant is expected to be more effective for alleviating salinity stress. Furthermore, the effect of applying saline-tolerant bacteria with different frequencies combined with ameliorants has not been reported. Therefore, this research was conducted with a hypothesis that frequency of applying of saline-tolerant bacteria on different ameliorants can affect growth, yield and nutrient uptake of tomato in saline land.

\section{Results and discussion}

\section{Growth and Yield of tomato}

Salinity stress decreases growth and yield of plant. The results (Table 1.) showed that gypsum and cow manure as soil ameliorant had the same effect on the growth and yield of tomatoes in saline land, while the application of consortium saline tolerant bacteria significantly increased the growth and yield of tomatoes in saline land. This research revealed that three- and four-times application of consortium saline tolerance bacteria were able to increase plant height up to $23 \%$ and both leaves area and dry weight of plant up to $90 \%$, compared to control treatment. Increasing growth of plant due to the application of bacteria was also reported by Egamberdieva et al. (2017) suggesting that inoculation of bacteria from Pseudomonas extremorientalis can increase plant height of tomato plants up to $27 \%$ under saline conditions. Mayak et al. (2004) had also reported that the application of PGPR bacteria could increase both the fresh and dry weight of tomato plants in saline stress conditions.

The research showed that the application of consortium saline tolerance bacteria was able to improve the yield of tomato (Table 1). Fresh weight of fruit per plant increased by $85.51 \%$ with four times application of saline tolerance bacteria, compared to control treatment. It showed that fresh weight of fruits was increased in line with the application of saline-tolerant bacteria. Egamberdieva et al. (2017) also reported that inoculation of Pseudomonas extremorientalis increased the fresh weight of tomato fruit per plot $\left(1 \mathrm{~m}^{2}\right)$ by $22 \%$, compared to un-inoculated plants.

The total chlorophyll content of tomato leaves was measured on reproductive stage (Figure 1.). It showed 8$13 \%$ increase due to the application of consortium salinetolerant bacteria for all frequency. Total chlorophyll content of tomato leaf decreased under salinity stress (Taffouo et al., 2010). There was an increase in total chlorophyll content through the application of saline-tolerant bacteria. Total chlorophyll content was widely influenced by nutrient sufficiency. The plant response to high amounts of nitrogen was increase in the green pigment, which is in line with the total chlorophyll. Similarly, the increasing of chlorophyll content under salinity stress due to application rhizobacteria was also reported by Nadeem et al. (2006) on maize and Metwali et al. (2015) on faba bean.

Four times application of consortium saline tolerance bacteria also improved fruit quality according to the value of total sugar. The total sugar was increased equally with the application frequency of consortium saline tolerance bacteria. It means that the application of bacteria can improve the quality of tomato fruits under salinity stress. Shen et al. (2012) showed that application of PGPR bacteria from Bacillus pumilis species was able to improve the quality of tomato fruits of irrigated salt-water seeds by increasing total dissolved sugars. The results of research by Rodriguez et al. (2018) showed that inoculation of PGPR from Bacillus sp. was able to increase total dissolved solids in tomato fruits compared to plants un-inoculated with bacteria and inoculated with Pseudomonas and Aeromonas sp. The results of the research showed that the total sugar content ranged from $8.8-11.5 \%$. This value is still higher compared to the standard total value of tomato sugars at full maturity level, which is about $9.00 \%$ (Teka, 2013).

Bacteria have their own mechanism to adapt or live in stressed environments such as saline soil. They also have a mechanism to help plant grow well under salinity stress by playing their roles as bio-stimulant and bio-fertilizer. Bacteria are able to stimulate plant growth through the production of indole acetic acid (IAA) which has an important role in stimulating root growth. Patten and Glick (2002) reported that inoculated canola seeds using IAAproducing bacteria from Pseudomonas peptide species increased root length compared to un-inoculated plants and inoculated plants with mutant bacteria. lqbal et al. (2016) also reported that auxin-producing bacteria from Pseudomonas fluorescens and Serratia proteamaculans were able to increase the grain yield of maize up to $31 \%$. In addition, one of the plant responses to salinity stress is the overproduction of ethylene, which can inhibit plant growth. Bacteria from rhizobacteria species have been known to be able to produce Aminocyclopropane-1-Carboxylate Deaminase (ACC Deaminase) enzyme, which might regulate 
Table 1. Effect of Ameliorant and Frequency Application of Consortium Saline Tolerance Bacteria on Growth and Yield of Tomato in Saline Land

\begin{tabular}{|c|c|c|c|c|}
\hline Treatments & $\begin{array}{l}\text { Plant Height } \\
(\mathrm{cm})\end{array}$ & $\begin{array}{l}\text { Leaf Area } \\
\left(\mathrm{cm}^{2} \text { plant }^{-1}\right)\end{array}$ & $\begin{array}{l}\text { Dry Weight } \\
\text { of Plant } \\
\left(\text { g plant }^{-1}\right)\end{array}$ & $\begin{array}{l}\text { Fresh Weight } \\
\text { of Fruits } \\
\text { (g plant }^{-1} \text { ) }\end{array}$ \\
\hline \multicolumn{5}{|l|}{$\begin{array}{r}\text { Soil } \\
\text { Ameliorant }\end{array}$} \\
\hline Gypsum & $81.33 \pm 7.34$ & $1041.06 \pm 101.24$ & $51.33 \pm 2.08$ & $519.93 \pm 85.43$ \\
\hline Cow Manure & $77.87 \pm 2.00$ & $877.38 \pm 77.28$ & $51.51 \pm 4.31$ & $440.54 \pm 68.86$ \\
\hline HSD (5\%) & ns & ns & ns & ns \\
\hline \multicolumn{5}{|c|}{ Frequency Application of Consortium Bacteria } \\
\hline Control & $70.89 \pm 2.09 a$ & $635.47 \pm 72.58 a$ & $35.41 \pm 2.20 \mathrm{a}$ & $353.53 \pm 43.03 a$ \\
\hline Once & $75.89 \pm 3.13 a b$ & $847.35 \pm 128.80 a b$ & $45.68 \pm 8.13 a$ & $404.91 \pm 39.69 a b$ \\
\hline Twice & $79.72 \pm 5.16 a b$ & $964.26 \pm 92.96 a b$ & $45.96 \pm 1.72 \mathrm{a}$ & $467.02 \pm 127.4 a b$ \\
\hline 3 Times & $84.06 \pm 8.11 b$ & $1100.40 \pm 236.65 b$ & $57.96 \pm 7.97 b$ & $519.61 \pm 108.3 a b$ \\
\hline 4 Times & $87.45 \pm 10.86 b$ & $1248.63 \pm 118.78 b$ & $72.09 \pm 5.26 b$ & $655.86 \pm 36.47 b$ \\
\hline HSD (5\%) & 9.24 & 452.36 & 15.75 & 258.65 \\
\hline
\end{tabular}

Note. Mean \pm standard deviation. Means followed by different letter indicated significant difference at 0.05 significance level. ns: not significant

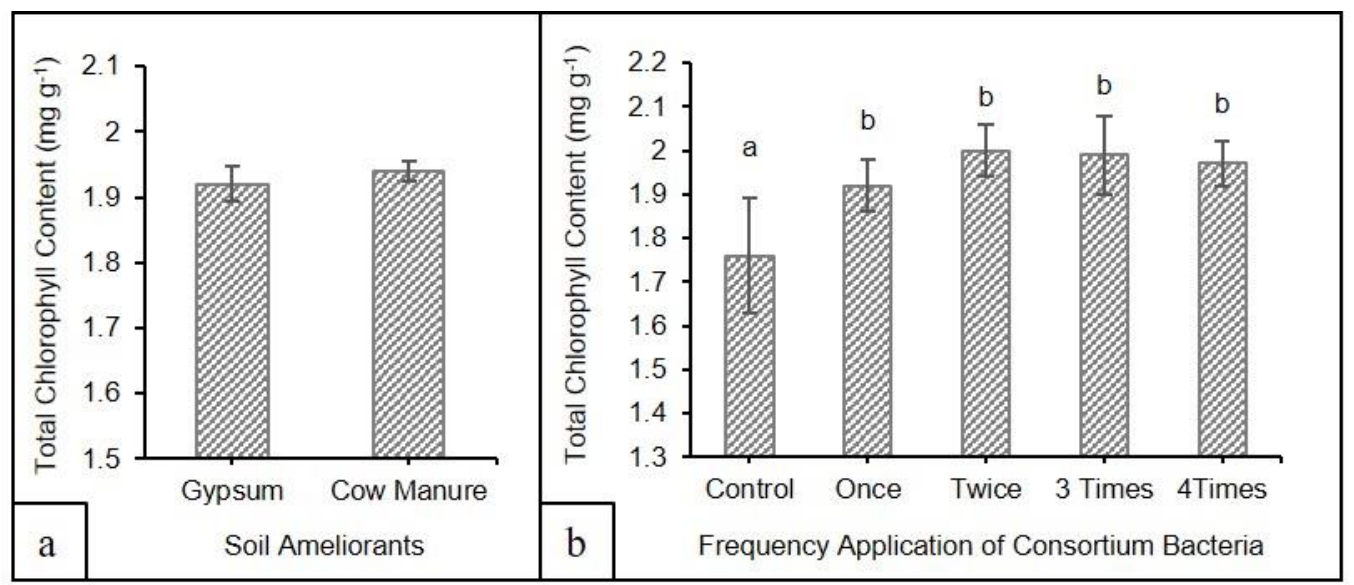

Fig 1. Total Chlorophyll Content of Tomato Leaves Affected by Ameliorants (a) and Application of Consortium Saline Tolerant Bacteria (b). Values followed by different letter indicated significant difference at 0.05 significance level.

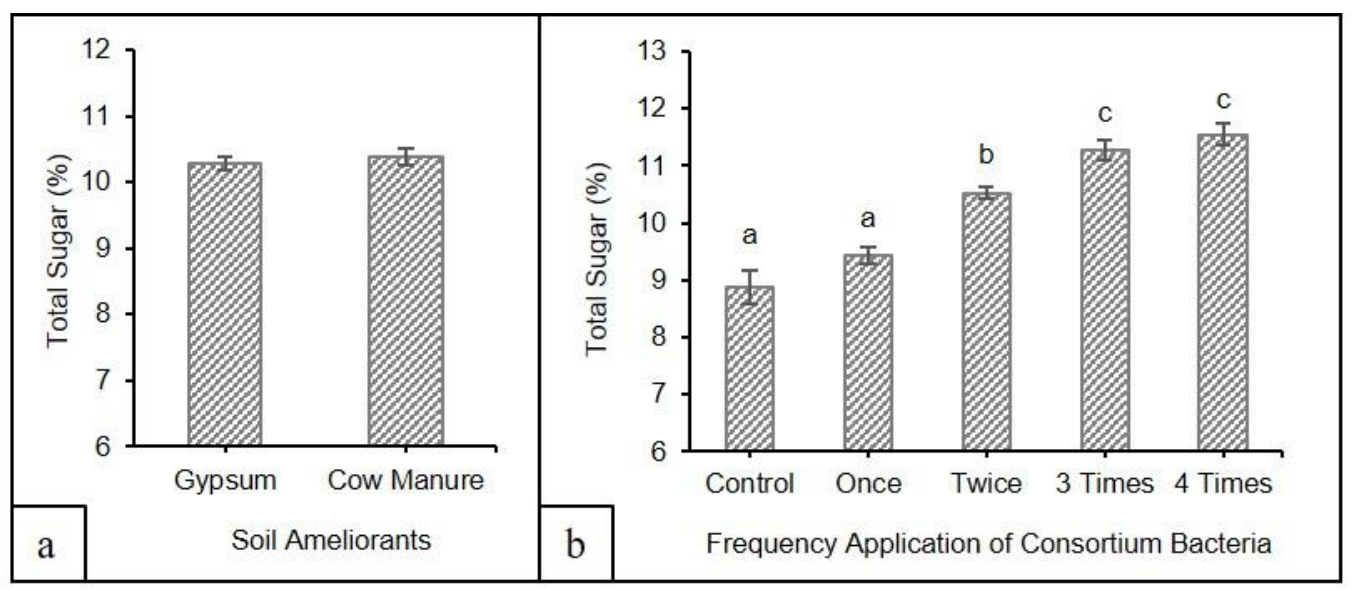

Fig 2. Total Sugar of Tomato Fruits Affected by Ameliorants (a) and Application of Consortium Saline Tolerant Bacteria (b). Values followed by different letter indicated significant difference at 0.05 significance level. 


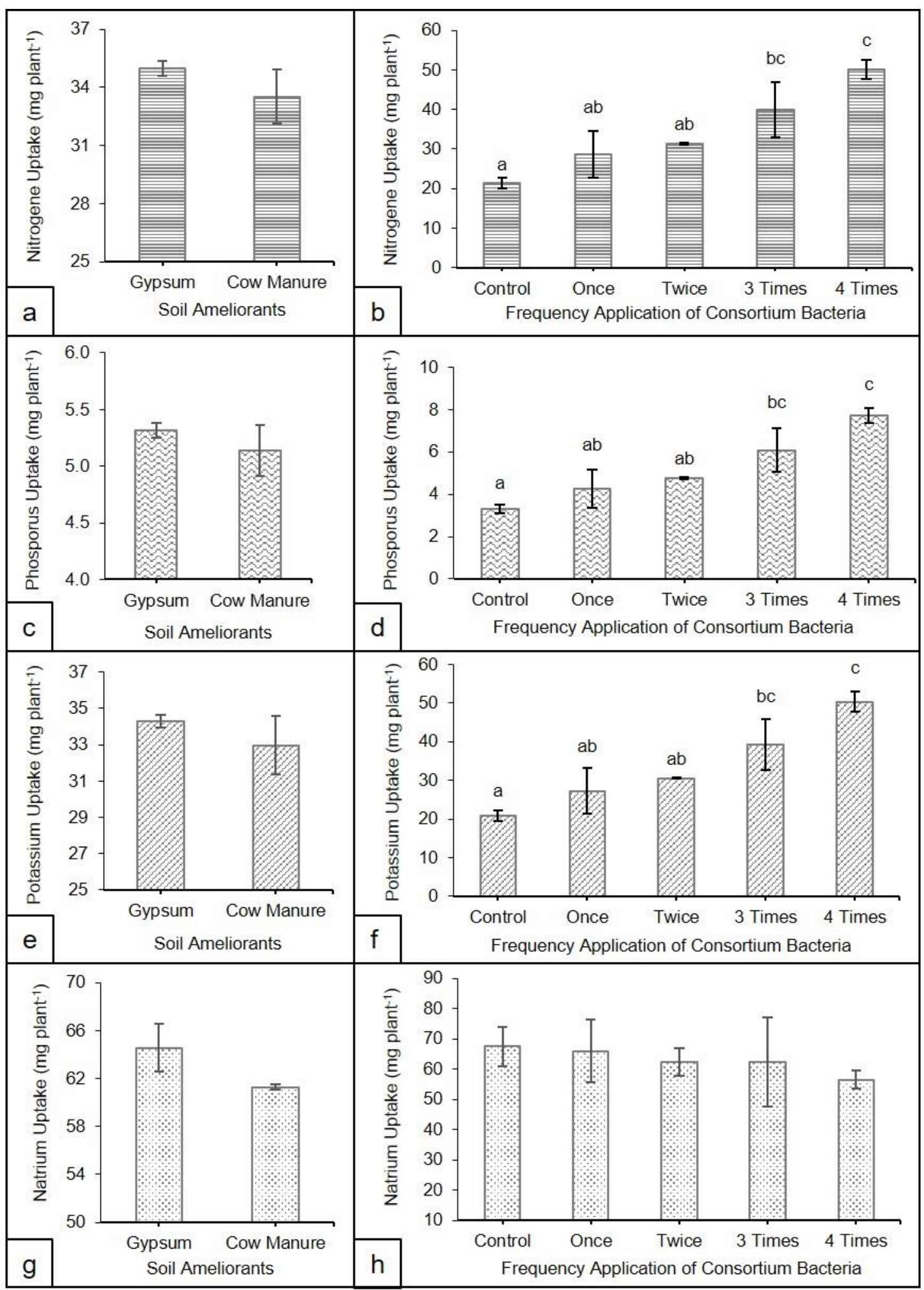

Fig 3. Nitogene Uptake of Tomato Affected by Soil Ameliorants (a) and Aplication of Consortium Saline Tolerant Bacteria (b); Phosporus Uptake of Tomato Affected by Soil Ameliorants (c) and Aplication of Consortium Saline Tolerant Bacteria (d); Potassium Uptake of Tomato Affected by Soil Ameliorants (e) and Aplication of Consortium Saline Tolerant Bacteria (f). Natrium Uptake of Tomato Affected by Soil Ameliorants (g) and Aplication of Consortium Saline Tolerant Bacteria (h). Values followed by different letter indicated significant difference at 0.05 significance level. 


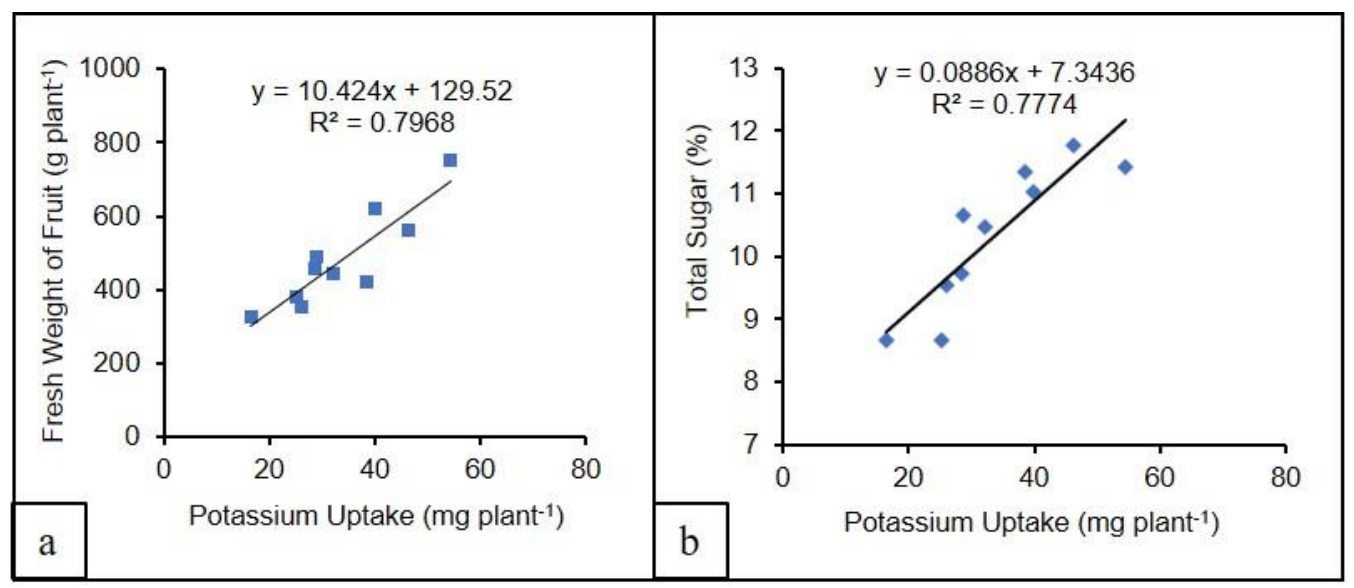

Fig 4. Regression Between Potassium Uptake and Fresh weight of Tomato Fruits (a) and Potassium Uptake and Total Sugar of Tomato Fruits (b).

the production of ACC, a precursor of ethylene (Glick, 2014). This shows that ACC-deaminase producing bacteria are able to improve the tolerance of plant growth under salinity stress. Zafar-ul-Hye et al. (2014) reported that PGPRcontaining ACC-deaminase from Pseudomonas syringae and Pseudomonas fluorescens species may improve yield of maize under drought and salinity stress.

\section{Nutrient Uptake}

Under salinity stress, the rate of nutrient uptake was limited. Generally, the result of this research (Table 2.) showed that gypsum and cow manure had the same effect on N, P, K and $\mathrm{Na}$ uptake of shoots. Nutrient uptake increased by the application of consortium saline tolerant bacteria. Three and four applications had a better effect on N, P and K uptake compared to the control treatment. Application of consortium saline-tolerant bacteria was able to alleviate salinity stress related to the value of $\mathrm{Na}$ which had a declining trend along with the increasing application frequency of saline-tolerant bacteria (Figure 3.). N, P and $\mathrm{K}$ uptake increased 85-135\% while Na uptake was reduced 8$16 \%$, compared to control.

The results of the research indicated that the application of consortium bacteria increased total nitrogen, phosphorous, and potassium uptake in shoots while sodium uptake showed a declining trend although it was not statistically significant. This shows that the application of bacteria can potentially increase nutrient uptake. Zameer et al. (2016) reported that PGPR is a group of bacteria that colonizes roots and helps plants take up nutrients such as N, P and K. Meanwhile, Castilo-Aguilar et al. (2017) showed that even seedlings inoculated with Panebacillus polymyxa were not significantly different in the nitrogen uptake of Capsicum chinense, but higher amounts of $\mathrm{P}$ and $\mathrm{K}$ uptake were identified compared to un-inoculated seedlings. Consortium application of bacteria is more effective than the application of single bacteria. Sharafzadeh (2012) reported that the application of Pseudomonas, Azotobacter and Azospirillum as a consortium resulted in higher amounts of $\mathrm{N}, \mathrm{P}$ and $\mathrm{K}$ uptake of tomato compared to single application of those bacteria. Na uptake in plants treated with bacteria application is lower than that in plants treated without bacteria. These results indicate that the application of bacteria can alleviate stress of the plant as evidenced by the decrease of $\mathrm{Na}^{+}$levels in the plant tissue. According to
Maathuis (2014), $\mathrm{Na}^{+}$is an ion that easily accumulates in cells of plants and at certain levels is toxic for plants. Ashraf et al. (2004) reported that rhizobacteria were able to produce exopolysaccharide compounds that can bind $\mathrm{Na}^{+}$in plant tissue and alleviate salinity stress of plants.

Yield and quality of fruit are greatly influenced by the adequacy of nutrients, especially $\mathrm{K}$ (potassium). Linear regression showed that fresh weight and total sugar of fruits are strongly influenced by potassium uptake (Figure 4). Potassium plays an important role in biochemical processes such as enzymes activation, carbohydrate metabolism, protein synthesis and ATP production which is dominant in regulating photosynthetic rate (Hasanuzzaman et al., 2018). Increasing fruit yield of tomato under salinity due to application of potassium was also reported by Amjad et al. (2014) and Sajyan et al. (2018). Potassium is also known to play a role in biosynthesis and sugar transfer. So, it also determines the quality of tomato fruits, especially the total sugar content. Javaria et al. (2012) reported that increasing $\mathrm{K}$ fertilization could increase total sugars and titratable acidity in tomato fruit, by $11.03 \%$ and $121.87 \%$, respectively.

\section{Materials and methods}

\section{Plant materials}

Plant material used in this research was tomato seed Variety of Tymoti F1. Seed were sowed into plastic nursery and transplanted to the field after 21 days after sowing.

\section{Bacteria isolates preparation}

Bacteria used in this study was consortium of three isolates namely $\mathrm{SN} 13+\mathrm{SN} 22+\mathrm{SN} 23$. They were isolated from rhizosphere of plants grown in the soil of saline-prone regions of coastal area of Lamongan, in coastal East Java Indonesia. These three isolates were developed and tested (selection of salinity tolerance, hypersensitivity test on tobacco leaves, IAA production test and nitrogen fixing test) at Bacteriology Laboratory of Pests and Plant Disease Department, Faculty of Agriculture, University of Brawijaya. The molecular identification from our previous research (Cahyaty et al. 2017) showed that SN 13, SN 22 and SN 23 belong to the species of Streptomyces sp., Bacillus sp. and Corynebacterium sp. 
Each bacteria isolate was cultured on Nutrient Agar (NA) medium with strike plate methods and then incubated for 24 hours. Bacteria grown from NA, were collected using inoculation needles and then dipped in the $100 \mathrm{ml}$ Nutrient Broth (NB) liquid medium. Bacteria suspensions were shaken for $2 \times 24$ hours at a speed of $150 \mathrm{rpm}$ and then obtained the Optical Density (OD) using spectrophotometer. After obtaining $O D$ value $\geq 1$, the bacterial suspensions were diluted to a density of $1 \times 10^{9} \mathrm{cfu} \mathrm{m}^{-1}$. Preparation of consortium bacteria was done by mixing each bacteria with the same ratio.

\section{Experimental site and design}

Field experiment was conducted at Sidomukti Village District of Brondong Lamongan East Java, Indonesia. The soil had EC $4.12 \mathrm{dS} \mathrm{m}^{-1}, \mathrm{pH} 7.1, \mathrm{C}$-organic $1.39 \%$, N-total $0.16 \%$, P 8.61

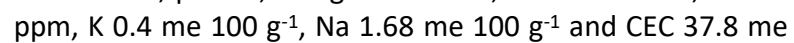
$100 \mathrm{~g}^{-1}$. Research was arranged using split plot design with three replications. The main plot was soil ameliorants namely A1: Gypsum and A2: Cow manure while subplots were application frequency of consortium saline tolerance bacteria namely F0: Control (without bacterial isolates, F1: Once (soaking seeds), F2: Twice (soaking the seeds and transplanting), F3: Three times (soaking seeds, transplanting and 2 WAT), F4: Four times (soaking seeds, transplanting, 2 and 4 WAT). Application ameliorants of gypsum with doses 5 ton ha-1 and Cow manure cow manure 20 ton ha- ${ }^{-1}$. Gypsum and cow manure were given to the soil 10 days before transplanting according to treatments.

\section{Seed treatment and maintenance}

Tomato seeds were treated with bacteria by soaking the seeds into warmed water $\left(32^{\circ} \mathrm{C}\right)$ for about fifteen minutes and then soaking into bacteria suspension $\left(1 \times 10^{9} \mathrm{cfu} \mathrm{mL}^{-1}\right)$ with a concentration of $5 \mathrm{~mL} \mathrm{~L}^{-1}$ for about 2 hours. Seeds untreated with bacteria were only soaked with distilled water. Seeds were sown using a plastic nursery with soil and cow manure as medium. After 3 weeks, the tomato seedlings were ready to be transplanted. Tomato seedlings were transplanted to bedded land covered with plastic mulch with plant spacing of $50 \times 50 \mathrm{~cm}$. Standard agronomic practices were followed to allow the plant to grow well. Replanting was done up to 2 weeks after transplanting. Watering was done manually using buckets once a day and every day after the plants were just transplanted up to 1 week after transplanting, then continued once every 2 days up to 14 weeks after transplanting (at harvesting). The applied fertilizers were urea, super phosphate (SP 36), and NPK fertilizer (16-16-16). Urea and SP 36 were applied with $30 \%$ doses of $150 \mathrm{~kg}$ hectare ${ }^{-1}$ of Nitrogen and $120 \mathrm{~kg}$ hectare ${ }^{-1} \mathrm{P}_{2} \mathrm{O}_{5}$ as basal fertilizer. NPK fertilizer was applied in three splits (15, 30, and 45 days after transplanting) with a dose of $500 \mathrm{~kg}$ hectare ${ }^{-1}$. Pest and diseases control were done using organic pesticide OrgaNeem extracted from Azadirachta indica at a concentration of $5 \mathrm{~mL} \mathrm{~L}^{-1}$.

\section{Application of bacteria}

Consortium bacteria isolates were applied according to the treatments by drenching the soil around each plant with 20 $\mathrm{mL}$ of bacteria suspension $\left(1 \times 10^{9} \mathrm{cfu} \mathrm{mL}^{-1}\right)$ with concentration $22.5 \mathrm{~mL} \mathrm{~L}^{-1}$. Bacteria was applied in the afternoon to keep the bacteria isolates from direct solar radiation.

\section{Growth and Yield Measurement}

Plant growth parameters including plant height, leaf area, and dry weight of plants were measured by random selection of four plants at 8 weeks after transplanting for each treatment. Meanwhile, yield parameters including fresh weight of fruit per plant were measured from 15 selected plants of each treatment. Fruits quality (total sugar of fruit) was recorded from 5 selected fruits at the full ripening maturity stage using the spectrophotometry method.

Total chlorophyll content of tomato leaves was measured using chlorophyll meter SPAD-502 at the reproductive stage and converted according to Jiang (2017) by the following equation:

Total chlorophyll $\left(\mathrm{g} \mathrm{mg}^{-1}\right)=[0.0306(\mathrm{x})+0.1443]$

( $x$ = value read by chlorophyll meter)

\section{Plant analysis}

Dried materials of plants were analyzed for nutrient contents such as total nitrogen, phosphorus, potassium and sodium. Total nitrogen content was determined by Micro Kjeldahl method (Stuart, 1936). Phosphorus content was determined by spectrophotometer method (Cook and Daughton, 1981). Potassium and sodium were determined by flame photometer method (Hald, 1946). Nutrient uptake was determined by multiplying the value of each nutrient and dry weight of shoots.

\section{Statistical analysis}

The collected data were analyzed using Analysis of Variance, then examined with $\mathrm{F}$ test at $5 \%$ error level and further with Honestly Significant Difference (HSD) at $5 \%$ error level. The correlation and regression among parameters were examined using SPSS version 16.

\section{Conclusions}

Application of consortium saline tolerant bacteria at four times applications (soaking seeds, transplanting, 2 and 4 weeks after transplanting) can improve yield and nutrient uptake of tomato grown in saline land. Application of consortium saline tolerant bacteria are not affected by soil ameliorant type. Gypsum and cow manure as soil ameliorant showed no different effect on yield and nutrient uptake of tomato grown in saline land. On tomato plant, consortium of saline tolerant bacteria was more effective when applied several times. It can be applied as early as seed treatment then repeated once or twice in the vegetative phase.

\section{Acknowledgements}

The authors are grateful to Ministry of Research, Technology, and Higher Education of Indonesia in cooperation with Community Service Research Institute (LPPM) of the University of Brawijaya for funding this research (338.139/UN10.C10/PN/2018).

\section{References}

Abdel-Fattah MK (2012) Role of gypsum and compost in reclaiming saline-sodic soils. J Agric Vent Sci. 1(3):30-38.

Ahmed K, Ghulam Q, Jami, AR, Nawaz MQ, Rahim A, Jabran $K$, Hussain M (2015). Gypsum and farm manure application with chiseling improve soil properties and performance of 
fodder beet under saline-sodic conditions. Int J Agric Biol. 17(6):1225-1230.

Amjad M, Akhtar J, Anwar-Ul-Haq M, Imran S, Jacobsen S (2014) Soil and foliar application of potassium enhances fruit yield and quality of tomato under salinity. Turk J Biol. 38:208-218.

Asghari R, Ahmadvand R (2018) Salinity stress and its impact on morpho-physiological of aloe vera. Pertanika J Trop Agric Sci. 41(1): 411-421.

Ashraf M, Hasnain S, Berge O, Tariq M (2004) Inoculating wheat seedling with exoplysaccharide-producing bacteria restrict sodium uptake and stimulates plant growth under salt stress. Biol Fert Soils. 40(3):157-162.

Bagdi DL, Kakraliya BL, Gathala MK (2011) Effect of plant growth regulators on physiological, biochemical traits, growth and yield of wheat (Triticum aesticum L.) under salt stress. Agric Sci Digest. 31(2):79-85.

Buttar G, Thind HS, Sekhon KS, Kaur A (2017) Management of saline-sodic water in cotton-wheat cropping system. J Agric Sci Tech. 19(2):465-474.

Cahyaty RAA, Aini N, Sumarni T (2017) Effect of rhizosphere bacteria application on saline tolerant to proline and chlorophyll contents of cucumber. Biosci Res. 14(4): 949954

Castilo-Aguilar C, Zuniga-Aguilar JJ, Guzman-Antonio A, Garruna R (2017) PGPR inoculation improves growth, nutrient uptake and physiologycal parameters of Capsicum chinenses plant. Int J Exp Bot. 86:199-204.

Cha-um S, Pokasombat Y, Kirdmane C (2011)_Remediation of salt-affected soil by gypsum and farmyard manure importance for the production of jasmine rice. Aust J Crop Sci. 5(4):458-465.

Cook AM, Daughton CG (1981) Total phosphorus determination by spectrophotometry. Meth Enzymol. 72: 292-295.

Daur I, Tatar O (2013) Effect of gypsum and brassin olide on soil properties, and berseem (Trifolium alexandrinum L.) growth, yield and chemical composition grown on saline soil. Legume Res. 36(4):306-311.

Egamberdieva D (2009) Alleviation of salt stress by plant growyh regulators and iaa producing bacteria in wheat. Acta Physiol Plant. 31(4):861-864.

Egamberdieva D, Davranov K, Wirth S, Hashem A, Abd_Allah FE (2017) Impact of salinity on plant-growth promoting and biological control abilities of root associated bacteria. Saudi J Biol Sci. 24(7):1-7.

Glick BR (2014) Bacteria with Acc deaminase can promote plant growth and help to feed the world. Micobiol Res. 169(1):30-39.

Gomes MD, Suzuki MS, Cunha MD, Tullii CF (2011) Effect of salt stress on nutrient concentration, photosynthetic pigments, proline and foliar morphology of Salvina auriculata Aubl. Acta Limnol Bras. 23(2): 164-176.

Grieve CM, Grattan S, Mass EV (2012) Plant salt tolerance. In W. W. Wallender, and K. K. Tanji (Eds.), Agricultural salinity assessment and management ASCE, Virginia. p.405-459.

Hald PM (1947) The flame photometer for the measurement of sodium and potassium in biological material. J Biol Chem. 167(2):499-510.

Hasanuzzaman M, Bhuyan MHMB, Nahar K, Hossain MD, Mahmud JA, Hossen MS, Masud AAC, Moumita, Fujita M (2018) Potassium: a vital regulator of plant responses and tolerance to abiotic stresses. Agron. 8(31):1-29.

Hardie M, Doyle R (2012) Measuring soil salinity. In S. Shabala, and T. A. Cuin (Eds.), Plant salt tolerance: methods and protocols, methods in molecular biology. Springer Science+Bussiness Media, p.415-425.

Iqbal MA, Khalid M, Zahir ZA, Ahmad R (2016) Auxin Producing plant growth promoting rhizobacteria improve growth, physiology and yield of maize under saline field conditions. Int J Agric Biol. 18(1):37-45.

Javaria S, Khan MQ, Bakash I (2012) Effect of potassium on chemical and sensory attributes of tomato fruit. J Anim Plant Sci. 22(4):1081-1085.

Jiang C, Johkan M, Hohjo M, Tsukagoshi S (2017) A correlation analyss on chlorophyll content and spad value in tomato leaves. Hort Res. 71:37-42.

Maathuis FJ (2014) Sodium in plants: perception, signaling and regulation of sodium fluxes. J Exp Bot. 65(4):849-858.

Maksimovic I, Ilin Z (2012) Effect of salinity on vegetable growth and nutrient uptake. In T. S. Lee (Ed.), Irrigation system and practices in challenging environments. In Tech, p.171-182.

Mayak S, Tirosh T, Glick BR (2004) Plant growth-promoting bacteria that confer resistance in tomato to salt stress. Plant Physiol Bioch. 42(6):565-572.

Metwali EMR, Abdelmoneim TS, Bakheit MA, Kadasa NMS (2015) Alleviation of salinity stress in faba bean (Vicia faba L.) plants by inoculation with plant growth promoting rhizobacteria (PGPR). Plant Omics J. 8(5):449-460.

Nadeem S, Zahir Z, Naveed M, Arshad M (2006) variation in growth and ion uptake of maize due to inoculation with plant growth promoting rhyzobacteria under salt stress. Soil Environ. 25(2):78-84.

Patten CL, Glick BR (2002) The role of bacterial indole acetic acid in the development of the host plant root system. Appl Environ Microbiol. 68(8):3795-3801.

Paul D, Lade HS (2014) Plant-growth-promoting rhizobacteria to improve crop growth in saline Soil: A Review Agron Sustain Dev. 34(4):737-752.

Pourbabaee AA, Bahmani E, Alikhani HA, Emami S (2016) Promoting of wheat growth under salt stress by halotolerant bacteria containing acc deaminase. J Agric Sci Tech 18(3):855-864.

Qadir M, Schubert S (2002) Degradation processes and nutrient constraints in sodic soils. Land Degrad Dev. 13(4):275-294.

Rodriguez GG, Palomeque $\mathrm{BE}$, Rios $\mathrm{PC}$, Resendez $\mathrm{AM}$, Escobedo LL, Galvan HS, Mata JS (2018) Influenze of rhizobacteria in production and nutraceutical quality of tomato fruits under greenhouse conditions. Rev Mexicana Cienc Agric. 9(2):367-379.

Sabareshwari V, Ramya A (2018) Coastal saline soil of india: a review. Agric Rev. 39(1):86-88.

Sajyan TK, Shaban N, Rizkallah J, Sassine YN (2018) Effects of monopotassium-phosphate, nano-calcium fertilizer, acetyl salicylic acid and glycinebetaine application on growth and production of tomato (Solanum lycopersicum) crop under salt stress. Agron Res. 16(3):872-883.

Sathee L, Sairam RK, Kushwaha SR (2013) Effect of long-term salinity stress on growth and nutrient uptake in contrasting wheat genotypes. Indian J Plant Physiol. 18(4):344-354.

Sharafzadeh S (2012) Effect of PGPR on growth and nutrients uptake of tomato. Int J Adv Eng Technol. 2(1):27-31.

Shen M, Kang YJ, Wang HL, Zhang XS, Zhao QX (2012) Effect of plant growth-promoting rhizobacteria (PGPRs) on plant growth, yield, and quality of tomato (Lycopersicon esculentum Mill.) under simulated sea water irrigation. J Gen Appl Microbiol. 58(4):253-262. 
Shrivastava P, Kumar R (2014) Soil salinity: a seiours environmental issue and plant growth promoting bacteria as one of the tools for its alleviation. Saudi J Biol Sci 22(2):123-131.

Stuart NW (1936) Adaptation of the micro-kjeldahl method for the determination of nitrogen in plant tissue. Plant Physiol. 11(1):172-179.

Taffouo VD, Nouck AH, Dibong SD, Amouguo A (2010) Effects of salinity stress on seedlings growth, mineral nutrients and total chlorophyll of some tomato (Lycopersicum esculentum L.) cultivars. Afr J Biotechnol. 9(33):5366-5372.

Talei D, Kadir MA, Yusop MK, Valdiani A, Abdullah MP (2012) Salinity effects on macro and micronutrients uptake in medicinal plant king of bitters (Andrographis paniculata Nees.). Plant Omics J. 5(3):271-278.

Teka TA (2013) Analysis of the effect of maturity stage on the postharvest biochemical quality characteristics of tomato (Lycopersicon esculentum Mill.) fruit. Int Res J Pharm Appl Sci. 3(5):180-286.

Unlukra A, Yurtyeri T, Cemek B (2017)_Effects of irrigation water salinity on evapotranspiration and spinach (Spinacia oleracea L. Matador) plant parameters in greenhouse indoor and outdoor conditions. Agron Res. 15(5):21832194.

Yadav NM, Bagdi DL, Kakralya BL (2011) Effect of salt stress on physiological, biochemical, growth and yield variables of wheat (Tritivum aesticum L.). Agric Sci Digest. 31(4):247253

Yilmaz H, Kulaz H 2019 The Effects of Plant Growth Promoting Rhizobacteria on Antioxidant Activity in Chickpea (Cicer arietinum L.) Under Salt Stress. Leg Res. 42(1):72-76.

Yu J, Yu Z, Fan GQ, Wang G (2016) Isolation and characterization of indole acetic acid producing root endophytic bacteria and their potential for promoting crop growth. J Agric Sci Technol. 18(5):1381-1391.

Zafar-ul-hye M, Farooq HM, Zahir Z, Hussain M (2014) Application of acc-deaminase containing rhizobacteria with fertilizer improves maize production under drought and salinity. Int J Agric Biol. 16(3):591-596.

Zameer MZ, Zahid H, Tabassum B, Ali Q (2016). PGPR potentially improve growth of tomato plants in saltstressed environment. Turk J Agric-Food Sci Technol $4(6): 455-463$. 